\title{
GROWTH INDICES AND PRODUCTIVITY IN SUGARCANE
}

\author{
Maurício dos Santos Simões ${ }^{1}$; Jansle Vieira Rocha²; Rubens Augusto Camargo Lamparelli* \\ ${ }^{1}$ UNICAMP/FEAGRI - Programa de Pós-Graduação em Engenharia Agrícola. \\ ${ }^{2}$ UNICAMP/FEAGRI - Depto. de Planejamento e Desenvolvimento Rural Sustentável, C.P. 6011 - $13083-970$ - \\ Campinas, SP - Brasil. \\ ${ }^{3}$ UNICAMP/CEPAGRI - Centro de Pesquisa Meteorológicas e Climáticas Aplicadas à Agricultura - 13083-970 - \\ Campinas, SP - Brasil. \\ *Corresponding author <rubens@cpa.unicamp.br>
}

\begin{abstract}
A knowledge about the temporal development of agronomic variables in sugarcane is a very important aspect for the development of crop yield prediction models using remote sensing, and further studies are still needed. This paper describes the temporal evolution of sugarcane biophysical parameters, such as total biomass, leaf area index, number of plants per meter, and productivity. During two seasons, a commercial field in Araras/SP, planted with variety SP80-1842, on the $4^{\text {th }}$ and $5^{\text {th }}$ cuts, was monitored on eight different dates, and data were obtained for $2 \mathrm{~m}$ of sugarcane in three crop rows at 18 sampling points. Linear and multiple regression analyses were used to study growth analysis and to correlate agronomic variables (leaf area index and number of plants per meter) with biomass and productivity. Gompertz model, a sigmoidal curve, was the best adjustment curve for total biomass and yield in relation to days after cutting $\left(\mathrm{r}^{2}=0.8987\right.$ and $\mathrm{r}^{2}=0.9682$, respectively); number of plants and leaf area index showed best fit with a cubic exponential model and a quadratic exponential model, respectively. Total biomass and cane productivity were well correlated with LAI in the first two stages of the sugarcane cycle using linear regression. At the end of the cycle, total biomass and cane productivity were more related to number of plants, and lower $\mathrm{r}^{2}$ values than in other stages were obtained by the models.
\end{abstract}

Key words: biomass, leaf area index, crop temporal evolution

\section{INDICADORES DE CRESCIMENTO E PRODUTIVIDADE DA CANA-DE-AÇÚCAR}

\begin{abstract}
RESUMO: O conhecimento do desenvolvimento temporal de variáveis agronômicas da cultura da cana-deaçúcar é um aspecto preponderante, e ainda pouco explorado, para o desenvolvimento de modelos de entendimento e predição da produção em estudos de sensoriamento remoto. O presente descreve a análise da evolução temporal de variáveis agronômicas da cana-de-açúcar como a biomassa total (BMT), produtividade $(T C H)$, índice de área foliar $(I A F)$ e número de plantas por metro $(N P M)$. Durante duas safras um talhão comercial em Araras/SP cultivado com a variedade SP80-1842 no $4^{\circ}$ e $5^{\circ}$ cortes foi acompanhado em oito campanhas de campo para a coleta de dados. O IAF, o NPM, a TCH e a BMT foram coletados em 18 amostras de $2 \mathrm{~m}$ em três linhas de cana-de-açúcar. Análise de regressão linear e múltipla foram usadas para a análise do crescimento da cultura e para o estudo da correlação e ajuste de modelos entre as variáveis agronômicas e a $B M T$ e a TCH. O modelo Gompertz, de curva sigmoidal, foi o modelo que melhor se ajustou para a curva de

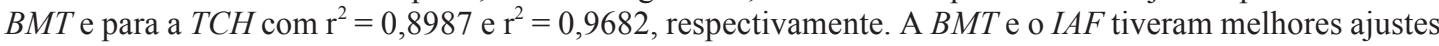
com curvas exponencial cúbica e exponencial quadrática, respectivamente. A $B M T$ e a $T C H$ foram bem relacionadas com o IAF nas duas primeiras fases do ciclo, ajustando-se regressões lineares. Para a fase de maturação, a $B M T$ e a $T C H$ foram mais relacionadas com o $N P M$ que com o $I A F$ e as curvas obtiveram valores menores de que $\mathrm{r}^{2}$ que as demais fases do ciclo.

Palavras-chave: biomassa, índice de área foliar, evolução temporal da cultura
\end{abstract}

\section{INTRODUCTION}

A knowledge about the temporal growth evolution of agricultural crops and their production cycles constitute initial and indispensable information for remote sensing, yield agroclimatic modeling, and yield prediction studies (Rudorff \& Batista, 1990).

At each developmental stage of a crop, agronomic and crop-specific variables vary; consequently, they deter- mine the crop's spectral behavior, help in providing an understanding of the influence of climate parameters on yield, interfere with agricultural planning, and determine the magnitude of physiological stress and final productivity values (Pellegrino, 2001; Teruel, 1995; Miocque, 1999). The analysis of a crop's growth is based on the sequential measurement of phytomass accumulation, and biophysical and agronomic variables, such as leaf area index $(L A I)$, and dry matter and green matter production rates to generate a de- 
velopment curve for the crop along its cycle (Magalhães, 1985). According to the author, in most agricultural crops the biomass development curve should be sigmoidal in shape, presenting three distinct stages.

In the specific case of sugarcane, some growth analysis studies have been developed for the crop, with a number of applications in mind, such as fertilization management (Gava, 1999), irrigation management (Teruel, 1995), growth models (Machado, 1981 \& Machado et al., 1982, Muchow et al., 1994), remote sensing and yield prediction (Pellegrino, 2001). However, further in-depth studies are still needed to provide detailed information on the crop's evolution and on the list of agronomic variables, such as number of plants per meter $(N P M), L A I$, and agricultural productivity, that is, the number of tons of sugarcane stalks per hectare that are suitable for processing (TSS). The present work fits into this context, with the objectives of generating information to describe sugarcane growth and to provide an understanding about the evolution of the crop's total aerial biomass (BMT), LAI, NPM, and productivity (TSS) for yield prediction applications.

\section{MATERIAL AND METHODS}

The study was conducted in a 27 ha commercial plantation located in the municipal district of Araras, SP, at a longitude range from $47^{\circ} 19^{\prime} 01^{\prime \prime} \mathrm{W}$ to $47^{\circ} 19^{\prime} 30^{\prime \prime} \mathrm{W}$ and a latitude range from $22^{\circ} 21^{\prime} 45^{\prime \prime} \mathrm{S}$ to $22^{\circ} 22^{\prime} 17^{\prime \prime} \mathrm{S}$, with variety SP80-1842, planted on 11/06/1997. The area's history is presented in Table 1 . This variety has been characterized as early, with medium tillering, having vigorous-growth stalks, medium-width and long leaves, with low soil fertility requirements, and showing higher ratoon productivity when compared with first-cut cane (plant cane) (Copersucar, 1993).

The predominant soils consist of a Rhodic Eutrudox, a Rhodic Hapludox, and a Typic Hapludox in this class, the occurrence of one area with moderate drainage is verified (Aquic Hapludox), as presented in Figure 1. The slope in the area does not exceed $12 \%$, which is a threshold value for green mechanized harvesting, according to the data from the 1:10,000 Araras II Chart (IGC,
1979). The climate in the study area has been identified by Oliveira (1982) as CWa according to Köppen's system, that is, a mesothermal climate with a dry winter.

During the 2000-2001 and 2001-2002 cropping seasons, the sugarcane vegetative cycle was monitored in the three main developmental stages of the crop, according to Magalhães (1985), with eight field campaigns performed on the dates below: first data collection - 11 October 2000 and 17 October 2001, second data collection - 03 February and 08 April 2001, 05 December and 11 May 2002, third data collection - 18 July 2001 and 01 August 2002.

The sampling points for collecting agronomic variables were distributed via a stratified sampling that took soil type into account, totaling 18 sampling points, where two linear meters of sugarcane were collected in three rows for each point, in order to estimate BMT, TSS, and NPM. Figure 1 illustrates the locations of sampling points and the type of sampling performed in the study area.

Biomass yield and productivity estimates can be achieved by measuring crop components; number of plants and stalk weight represent the most important crop components that can be measured, with good correlation with productivity, according to Yates (1969) and Gheller

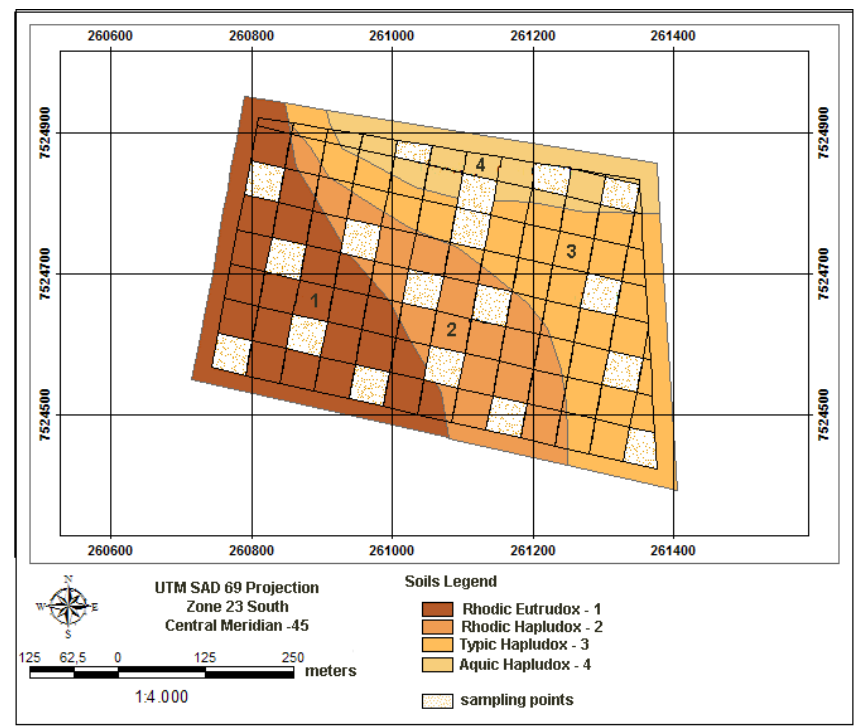

Figure 1 - Soil map and sampling point distribution

Table 1 - History and description of the study area

\begin{tabular}{|c|c|c|c|c|c|}
\hline Cropping season & 1998 & 1999 & 2000 & 2001 & 2002 \\
\hline Cut dates & $06 / 27$ and $09 / 03$ & $05 / 04$ and $05 / 26$ & $06 / 14$ & $07 / 11$ & $07 / 22$ \\
\hline Cut stages & $\begin{array}{l}\text { One-year old } \\
\text { sugarcane }\end{array}$ & Second cut & Third cut & Fourthcut & Fifthcut \\
\hline Type of cut & Mechanical, green & Mechanical, green & Mechanical, green & Mechanical, green & Mechanical, green \\
\hline Total area (ha) & 27.98 & 26.47 & 26.47 & 26.47 & 26.47 \\
\hline Yield $(t)$ & 2.558 & 2.844 & 2.415 & 1.960 & 1.913 \\
\hline Mean $\operatorname{TSS}\left(\mathrm{t} \mathrm{ha}^{-1}\right)$ & 91.4 & 107.4 & 91.2 & 74.0 & 72.3 \\
\hline
\end{tabular}

Source: Usina São João Açúcar e Álcool (2002). 
et al. (1999). The biomass yield and productivity estimate was calculated by separately analyzing aerial phytomass (leaves), stalk phytomass, and straw phytomass in each sampling point (Pellegrino, 2001), always using fresh or green mass data. The stalk water content variations were extremely low; in leaves, however, variation was higher, due to a more intense response of the leaves to lack of water and to differences in the number of leaves per plant (Primavesi et al., 1988). Even though these effects can introduce interpretation biases, since the objective was to work with data from commercial stands identical to those normally used in sugar mills, dry mass data were not included in this study.

In addition to these, $L A I$ is a biophysical parameter that could contribute toward the productivity estimates of crops (Teruel, 1995). LAI data collection was performed using indirect measurements with a LAI-2000 device, which estimates $L A I$ by measuring diffuse radiation in five angular bands (LI-COR, 1992). At each sampling point, one measurement of the diffuse radiation incident over the canopy and four under the canopy were taken; the average of these measurements represents the $L A I$ for the point. In addition, each measurement was repeated three times for the sake of replicates and later calculation of the mean $L A I$ value for the point.

In order to analyze sugarcane growth in both cropping seasons, we tried to fit curves that would describe BMT and TSS accumulation in tons per hectare $\left(\mathrm{t}\right.$ ha $\left.{ }^{-1}\right), N P M$ (number of plants per linear meter of sugarcane), and $L A I$ along the cropping season or relative to days after cutting $(D A C)$. The results were also evaluated in relation to the crop's physiological stages, to verify whether agreement existed with the crop's evolution and with the field data. Curve fitting regression analyses were performed based on the average data for the area, using the Ajuste software (Zullo Jr. \& Arruda, 1986) for biomass, productivity, number of plants, and $L A I$ data of both cropping seasons jointly.
The study of the relation between the agronomic variables measured (NPM, LAI) and TSS and BMT was performed by multiple linear regression, using the Stepwise procedure in the MiniTab 13 for Windows computing program. Regressions were generated for the three stages of the crop's growth cycle, namely establishment, vegetative development, and stabilization/ maturation, relating BMT and TSS with NPM and LAI in both cropping seasons under study. Thus, the data were subdivided into establishment, vegetative development, and maturation to generate multiple regressions using data from both cropping seasons jointly, in order to increase the volume of data and the degrees of freedom of the regressions. A total of nine regression models were obtained, representing the establishment, vegetative development, and maturation stages, as well as the establishment and vegetative development stages together, in addition to the entire cycle, with data from the three stages.

An analysis of the efficacy percentage for each model was performed using $\mathrm{r}^{2}$ as an indicator, by means of the model adequacy test through Analysis of Variance (ANOVA) to evaluate the significance of the model; the normality of residues was verified by Ryan-Joiner test, and the autocorrelation of residues was verified by Durbin-Watson test, to determine whether the proposed models should be accepted or not.

\section{RESULTS AND DISCUSSION}

The mean BMT, TSS, NPM, and $L A I$ data for the area, in each cropping season, showed the same behavior in both cropping seasons (Table 2 and Figure 2), similar to those obtained by Robertson et al., (1996). $L A I$ was the only variable exhibiting a different behavior in each cropping season. In the second cropping season, $L A I$ showed a marked decline in the mean values of the crop's growth stages, modifying the shape of

Table 2 - Characterization of variety SP80-1842, $4^{\text {th }}$ and $5^{\text {th }}$ cuts, in the region of Araras/SP in the 2000/2001 and 2001/2002 cropping seasons.

\begin{tabular}{|c|c|c|c|c|c|c|c|c|c|c|c|}
\hline Date & DAC & Stage of cycle & Height & NPM & $\mathrm{CV} \%$ & LAI & $\mathrm{CV} \%$ & TSS & $\mathrm{CV} \%$ & $\mathrm{BMT}$ & $\mathrm{CV} \%$ \\
\hline & & & $\mathrm{m}$ & & & & & $\mathrm{t} \mathrm{ha}^{-1}$ & & $\mathrm{t} \mathrm{ha}^{-1}$ & \\
\hline $10 / 11 / 00$ & 118 & Establishment & 0.80 & 24.96 & 10.6 & 0.92 & 54.2 & & & & \\
\hline $02 / 03 / 01$ & 233 & Vegetative growth & 1.80 & 16.80 & 9.5 & 3.34 & 20.3 & 58.63 & 6.4 & 78.28 & 5.4 \\
\hline $04 / 08 / 01$ & 297 & Vegetative growth & 3.20 & 14.45 & 11.1 & 3.38 & 30.3 & 67.40 & 4.2 & 86.11 & 3.6 \\
\hline 07/18/01 & 398 & Maturation & 3.50 & 10.79 & 11.2 & 1.47 & 67.4 & 92.77 & 4.4 & 108.28 & 4.3 \\
\hline $10 / 17 / 01$ & 81 & Establishment & 0.60 & 21.79 & 12.7 & 1.01 & 44.8 & 13.11 & 13.4 & 13.11 & 19.0 \\
\hline $12 / 05 / 01$ & 130 & Vegetative growth & 2.00 & 23.57 & 7.9 & 2.06 & 36.4 & $25.13 *$ & 9.0 & $25.13 *$ & 12.8 \\
\hline $05 / 11 / 02$ & 287 & Vegetative growth & 2.80 & 14.80 & 11.9 & 1.88 & 39.5 & $33.78 * *$ & 7.0 & $33.78 * *$ & 7.0 \\
\hline $08 / 01 / 02$ & 369 & Maturation & 3.20 & 10.23 & 13.7 & 1.56 & 38.4 & 88.63 & 4.9 & 111.63 & 4.1 \\
\hline
\end{tabular}

*Biomass at 97 days after cutting. **Biomass at 130 days after cutting.

NPM-number of plants per meter, LAI-leaf area index, TSS-productivity, and BMT-total biomass for the crop. 
the temporal development curve and changing the maximum value. These differences could be associated with the status of the crop, since a high occurrence of damping-off was verified, making it difficult to measure $L A I$, or interfering with measurements, by exposing the stalks and decreasing the amount of leaves visible in measurements performed with the LAI 2000 device.

LAI showed a slow growth behavior at the initial stage of the cycle, followed by a rapid growth stage in both cropping seasons (Figure 2). After this stage, LAI growth began to decline, reaching stability, and then finally beginning a stage when values decreased. At the stabilization stage, even if the $L A I$ value for the crop biomass increase, it has already reached its maximum value and stops growing. This behavior was similar to that found by Teruel (1995) and Pellegrino (2001), demonstrating that, even when NPM decreases, the leaf area index continues growing until the crop's maturation stage.

$N P M$ has a very unique evolution, characterized by a high $N P M$ value at the initial stage of development, known as tillering. As the crop develops, the primary and secondary tillers dominate the aerial space, causing the death of tillers that sprout at a later time, leading to a de-
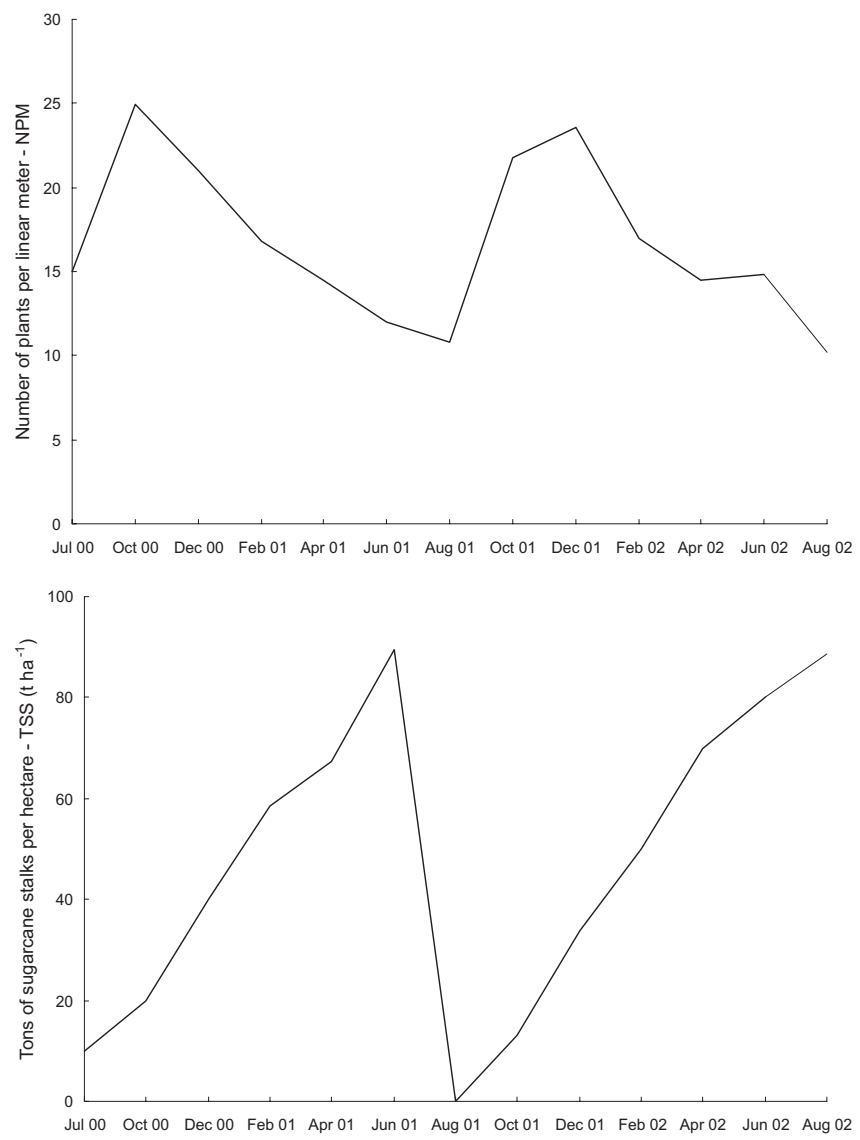

crease and stabilization of the number of plants per meter at approximately 10 plants per meter (Primavesi et al., 1988).

When a comparison is made between the mean agricultural productivity values (TSS) for the study area using the 18 sampling points (Table 2) and the mean yield for the area obtained by the sugar mill, by means of the total yield weight for the area measured on the sugar mill's balance divided by the harvest area (Table $1)$, there were differences in productivity values. Probably, the sampling method overestimated productivity, due to sample representativeness, size, and location within the stand. The high variability verified between samples within the stand, expressed by the coefficient of variation $(\mathrm{CV} \%)$, presented in Table 2 , show both the high spatial variability of the studied variables and the need for a more precise sampling to estimate the data. In addition to that is the fact that Gompertz model overestimated BMT and TSS, as shown in Figure 3. On the other hand, in the productivity calculation performed by the sugar mill, some accidentally burnt areas were taken into account in the total harvest area, decreasing the mean productivity of the stand and contributing toward the difference between the mean values obtained by the sugar mill and by the performed sampling.
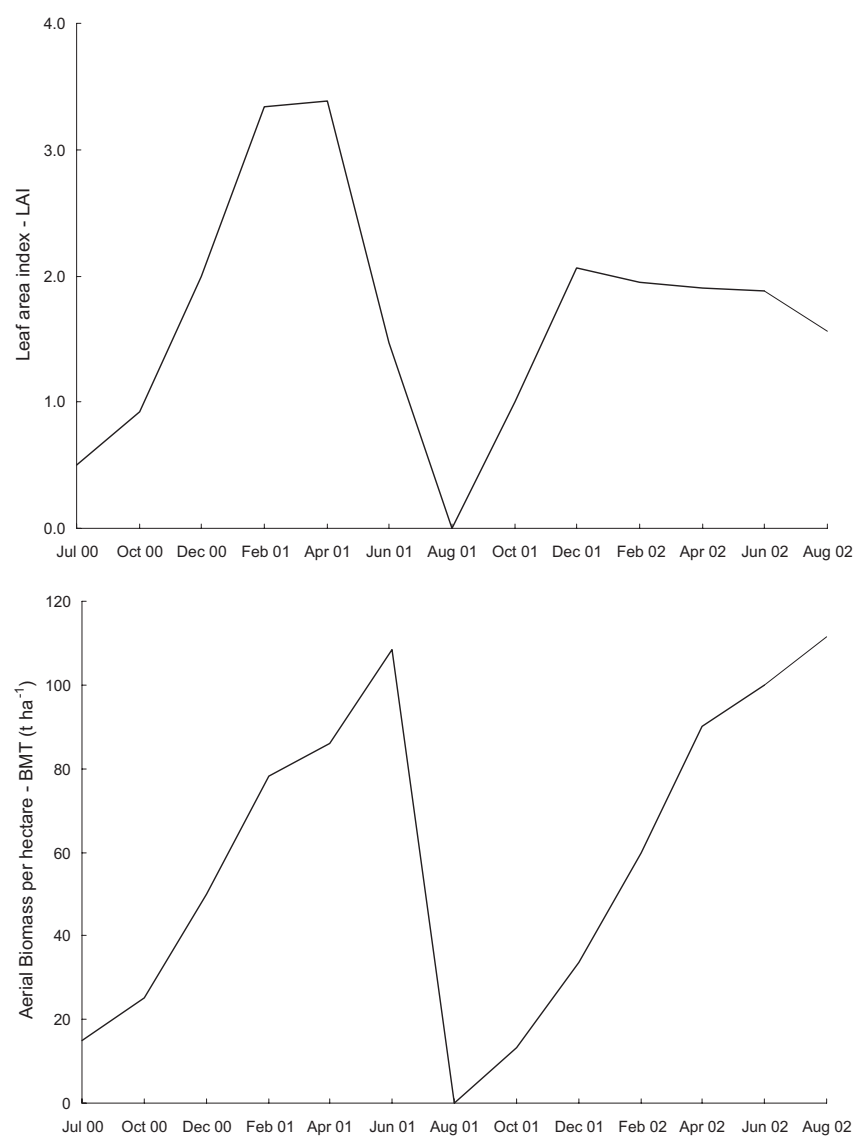

Figure 2 - Temporal evolution for total biomass (BMT), productivity (TSS), number of plants per meter (NPM), and leaf area index (LAI) (mean data of 18 samples) of variety SP80-1842 in the 2000/2001 and 2001/2002 cropping seasons. 

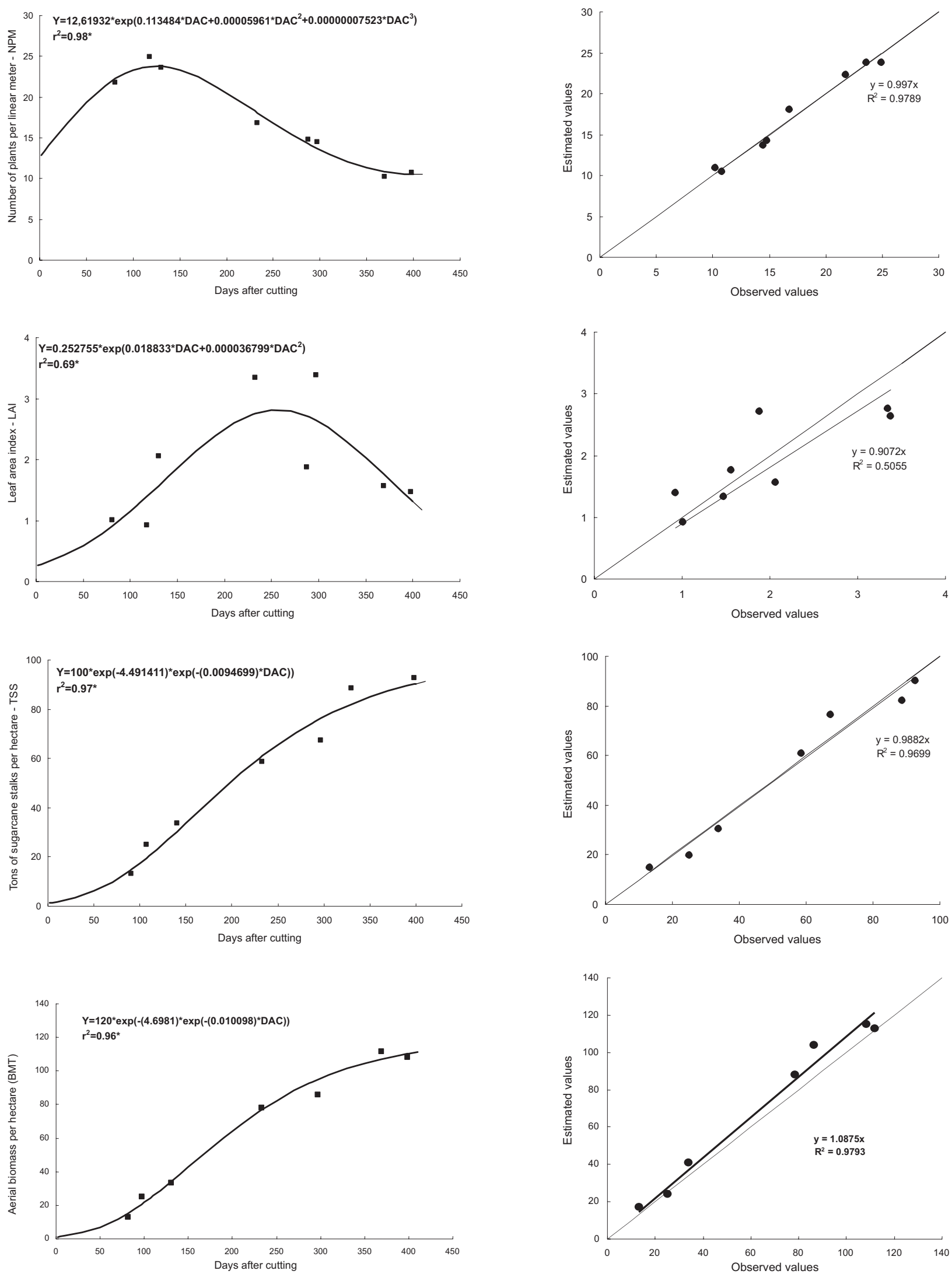

Figure 3 - Cubic Exponential Model fitted to NPM, Quadratic Exponential Model fitted to LAI and Gompertz Models fitted to BMT and TSS, obtained for the 2000/2001 and 2001/2002 cropping seasons. Relation between values observed in the field and values estimated with the empirical models.

*significance at $1 \%$ (F test).

Sci. Agric. (Piracicaba, Braz.), v.62, n.1, p.23-30, Jan./Feb. 2005 
The $B M T$ accumulation results in both cropping seasons, adjusted as a function of $D A C$, are presented in Figure 3. $B M T$ accumulation for the entire area had its behavior described by Magalhães (1985), and was also obtained by Muchow et al., (1994), Gava (1999), and Pellegrino (2001) in sugarcane. The behavior is characterized by an initial stage with slow growth and little biomass accumulation; the assimilation of photosynthates is directed toward sugarcane tillering, yielding a large number of plants per meter, which can be verified in the data analysis for number of plants per linear meter (Figure 2). The second stage is characterized by a period of intense vegetative growth, expressed by an increase in leaf area index, aerial biomass, and weight of tillers (stalks). The final stage is identified in the temporal analysis as the stage when sugarcane stops increasing its biomass and enters the maturation stage. This behavior can be verified by decreases in $L A I$ and number of stalks per meter, and by an increase in stalk biomass and a decrease in leaf biomass.

The model that best fitted BMT was Gompertz model, a sigmoidal model that allows a good representation of the asymptotic stage that is characteristic at the end of the crop cycle, obtained with a coefficient of determination $\left(\mathrm{r}^{2}\right)$ of 0.90 , with statistical significance at $1 \%$ (F test). The same did not occur with other models, such as the cubic and the logistic models which, although obtaining high coefficients of determination $\left(\mathrm{r}^{2}\right)$, did not show significance at the $1 \%$ level by $\mathrm{F}$ test; it was therefore clear that although the curves were well fitted to the sampled points, the mean behavior of $B M T$ could not be explained by them. Even though Gompertz model fitting obtained a high coefficient of determination, it overestimated the measured BMT data, showing a more accelerated growth at the vegetative development stages (Figure 3). At the initial stage and at the end of the development cycle, Gompertz model practically did not underestimate the values measured in the field, demonstrating that it was better fitted to this stage and to the end of the cycle than to the stage when the crop was developing.

Gompertz curve obtained the best fitting for $\mathrm{TCH}$, with an $r^{2}$ of 0.96 and statistical significance; the linear fitting curve was also significant; however, it does not provide a biological explanation for the crop's development (Figure 3). An analysis of the divergence between measured values and values estimated by the model, Figure 3, shows that Gompertz model provided an excellent explanation for the behavior, and correctly estimated sugarcane productivity, opening up the possibilities for its use in sugarcane productivity prediction and forecast.

In view of NPM's differential temporal behavior in relation to other studied variables, the best fitted model was the Cubic Exponential model, since it contemplates the differences in this parameter at the development stages, and because it models the final stabilization stage of the number of plants per meter.

The LAI parameter obtained the poorest fitting among all variables studied. The best fitting model for $L A I$, which showed consistency with the crop's physiological development was the Quadratic Exponential model. Even though this model represents the stages of rapid $L A I$ increase in the beginning of the crop's cycle, and then stabilization and a slight decline at the maturation stage, as a consequence of the collected data, the model exaggerated the $L A I$ reduction at the end of the cycle, creating a biased behavior in relation to what was observed by Machado (1981) in his studies. As previously pointed out, the possible reasons could be the high sugarcane lodging index observed in the area by the end of the second cropping season, contributing toward a reduction in $L A I$ values at the end of the cycle and toward the biased behavior shown by the curve. In addition, the $L A I$ data showed high coefficient of variation values, demonstrating that data collection could have been influenced by other factors, such as canopy height and amount of diffuse solar radiation, which are parameters identified by Xavier (2003) as causing problems in $L A I$ estimates obtained with LAI 2000.

The models resulting from multiple regressions using Stepwise for the establishment, vegetative development, and maturation stages of the crop cycle in both cropping seasons studied are presented in Table 3, where column Phenology refers to the cycle stage of data used to generate the regressions, column Model presents the models obtained, column $\mathbf{n}$ refers to the number of samples employed in the regression, and column $\mathbf{r}^{2}$ corresponds to the coefficient of determination values obtained by the models.

Based on an analysis of the models, it can be verified that they always obtained $r^{2}$ values above 0.7 , therefore with a good fitting. The Stepwise method sometimes ended up suggesting that one of the variables should be removed from the models, transforming seven multiple regressions into simple linear regressions.

An analysis of the models obtained at the initial and intermediate development stages revealed that the factor with the greatest influence on $B M T$ was $L A I$ (leaf canopy), while the contribution of $N P M$ was statistically negligible. Since no stalk formation occurs at the initial stage, BMT is identical to TSS; therefore, only one model was generated for this stage. It is understandable that $B M T$ and TSS strongly depend on the volume of leaves and less on the number of plants at this stage of the crop's cycle, since the volume of leaves can compensate for a smaller number of plants and better utilize the aerial space (Primavesi et al., 1988). A possible explanation for the non-significance of NPM is maybe the high variability found for this variable at the establishment and development stages, when the crop is experiencing intense 
Table 3 - Multiple regression models obtained with data from two cropping seasons studied.

\begin{tabular}{llll}
\hline Phenology & \multicolumn{1}{c}{ Model } & $\mathrm{N}$ & $\mathrm{r}^{2}$ \\
\hline Establishment & $B M T=15.2^{*} L A I$ & 36 & $0.88^{*}$ \\
Vegetative dev. & $T S S=18.1^{*} L A I$ & 22 & $0.96^{*}$ \\
Vegetative dev. & $B M T=24.3^{*} L A I$ & 23 & $0.96^{*}$ \\
Maturation & $T S S=8.32^{*} N P M$ & 29 & $0.97^{*}$ \\
Maturation & $B M T=8.64 * N P M+11.1 * L A I$ & 28 & $0.98^{*}$ \\
E + VD & $T S S=34.441 \mathrm{Ln}(L A I)+15.473$ & 58 & $0.71^{*}$ \\
E + VD & $B M T=0.500^{*} N P M+25.1 * L A I$ & 59 & $0.93^{*}$ \\
E+VD+M & $T S S=21.8 * L A I$ & 80 & $0.76^{*}$ \\
E+VD+M & $B M T=28.0^{*} L A I$ & 84 & $0.72 *$ \\
\hline
\end{tabular}

E - Establishment, VD - Vegetative Development, M - Maturation

*significance at the $1 \%$ level (F Test)

tillering. The temporal behavior of $N P M$, decreasing as the crop develops and therefore having an inversely proportional behavior in relation to BMT and TSS growth, could be also another possible explanation for the absence of correlation with $B M T$.

The fitting of linear models for the behavior of TSS and BMT in relation to LAI at the initial stage of the cycle, suggests that these data show a linear relationship when analyzed separately; this fact was also observed in the temporal accumulation analysis of the variables presented in Figure 3, where temporal accumulation for TSS and $B M T$ presented a linear rising behavior.

At the final development stage, however, NPM became relevant in explaining both $B M T$ and TSS. At this stage, BMT and TSS are intimately related to NPM, since sugarcane yield is a function of the number of plants per meter and of the individual weight of each sugarcane plant, as mentioned by Primavesi et al. (1988). This behavior performed as expected. Together with the high correlation of TSS with NPM, LAI values underwent a marked decrease during this stage, also decreasing their importance in the regression (Teruel, 1995).

Using data for the establishment and vegetative development stages jointly, the regressions showed an exponential relation between $L A I$ and TSS, in agreement with the relation found by Pellegrino (2001). This relation showed a better fitting because it represents a stage when biomass and productivity will no longer increase even when $L A I$ is increased, a fact that is not observed in linear models. In the case of $B M T$, the regression showed dependence, both on $L A I$ and on NPM, suggesting that during these two stages, $B M T$ is a function of both $L A I$ and $N P M$, even if during the establishment and vegetative development stages, studied separately, there was no significant relation with NPM. Thus, the use of more than one season to develop biomass or productivity estimation models can be improved by using more than one crop development stage.
In the study of data for the entire cycle and in both cropping seasons studied, the relations showed smaller $r^{2}$ values and smaller significance than those found in the studies for the three stages separately, and for the first two stages jointly. This could be due to a marked decrease in NPM and $L A I$ at the end of the cycle, compromising the correlation when the entire cycle is taken into consideration. In addition, the data for the end of the cycle showed the highest variability, also contributing negatively toward curve fitting. Even then, the models obtained when all collected data were taken into consideration showed correlation with the $L A I$ variable, excluding the $N P M$ variable from the model, with an $\mathrm{r}^{2}$ of 0.76 for TSS and 0.72 for BMT.

\section{CONCLUSIONS}

The curves that best fitted total biomass (BMT) and productivity (TSS) increases in sugarcane, in relation to numbers of days after cutting $(D A C)$, were sigmoidalshaped. The cubic exponential and quadratic exponential models best fitted the development of number of plants per meter $(N P M)$ and leaf area index $(L A I)$.

$T S S$ and $B M T$ were more influenced by $L A I$ than by $N P M$ at the establishment and vegetative development stages. In turn, at the maturation stage, TSS was basically influenced by NPM.

The use of regression models to estimate biomass and productivity in sugarcane, using agronomic variables such as $L A I$ and NPM still needs to be improved by the introduction of other variables, derived, for example, from soils and remote sensing data, improving their potential for use in yield prediction jobs.

\section{ACKNOWLEDGEMENTS}

To FAPESP (Proceeding 99/09091-1), to Usina São João, represented by Agronomists João Martins and João Batista Saccomanno, for making the study area available and for support during data collection, and to Centro de Tecnologia Copersucar for support during data collection. 


\section{REFERENCES}

COOPERATIVA DE PRODUTORES DE CANA, AÇÚCAR E ÁLCOOL DO ESTADO DE SÃO PAULO - COPERSUCAR. Quarta geração de variedades de cana-de-açúcar Copersucar. Piracicaba:Centro de Tecnologia Copersucar, 1993. 18p. (Boletim Técnico, ed. especial).

GAVA, G.J.C. Utilização de nitrogênio da Uréia $\left({ }^{15} \mathrm{~N}\right)$ e da palhada $\left({ }^{15} \mathrm{~N}\right)$ por soqueira de cana-de-açúcar no manejo sem despalha a fogo. Piracicaba: USP/CENA, 1999. 81p. (Dissertação - Mestrado).

GHELLER, A.C.A.; MENEZES, L.L.; MATSUOKA, S.; MASUDA, Y.; HOFFMANN, H.P.; ARIZONO, H.; GARCIA, A.A.F. Manual de método alternativo para medição da produção de cana-de-açúcar. Araras: UFSCar, CCA, DBV, 1999. 7p. Disponível em: <http:// www.dbv.cca.ufscar.br/pmgca $>$. Acesso em: Mar. 2000.

INSTITUTO GEOGRÁFICO E CARTOGRÁFICO DE SÃO PAULO - IGC. Carta Planialtimétrica Araras II. São Paulo: IGC, 1979. Escala $1: 10.000$.

LI-COR. LAI-2000 plant canopy analyser: Instruction manual. Nebraska: Li-Cor Inc. Lincoln, Nebraska, 1992. 182p.

MACHADO, E.C. Um modelo matemático-fisiológico para simular o acúmulo de matéria seca na cultura de cana-de-açúcar (Saccharum sp.). Campinas: UNICAMP/FEA, 1981. 115p. (Dissertação - Mestrado).

MACHADO, E.C.; PEREIRA, A.R.; FAHL, J.I.; ARRUDA, H.V.; CIONE, J. Índices biométricos de duas variedades de cana-de-açúcar. Pesquisa Agropecuária Brasileira, v.17, p.1323-1329, 1982.

MAGALHÃES, A.C.N. Análise quantitativa do crescimento. In: FERRI, M.G. Fisiologia vegetal. São Paulo: EDUSP, 1985. 350p.

MIOCQUE, J. Avaliação de crescimento e de produtividade de matéria verde da cana-de-açúcar na região de Araraquara-SP. STAB - Açúcar, Álcool e Subprodutos, v.17, p.45-47, 1999

MUCHOW, R.C., SPILLMAN, M.F., WOOD, A.W., THOMAS, M.R. Radiation interception and biomass accumulation in sugarcane crop grown under irrigated tropical conditions. Australian Journal of Agricultural Research, v.45, p.37-49, 1994.

OLIVEIRA, J.B. Levantamento pedológico do Estado de São Paulo: quadrícula de Araras. Campinas: Instituto Agronômico, 1982. 180p. (Boletim Técnico, 71).
PELLEGRINO, G.Q. Utilização de dados espectrais do satélite NOAA14/ AVHRR como fonte de dados para modelos matemáticos de estimativa da fitomassa da cana-de-açúcar. Campinas: UNICAMP/FEAGRI, 2001. 104p. (Tese - Doutorado).

PRIMAVESI, O.; DEUBER, R.; KORNDORFER, G.H.; FERNADES, A.C.; IDE, B.Y. Perfil de variedades - Biometria e análise do crescimento de cana planta-1985/1986. Piracicaba: Centro de Tecnologia Copersucar, 1988. 232p

ROBERTSON, M.J., WOOD, A.W., MUCHOW, R.C. Growth of sugarcane under high input conditions in tropical Austrália. Radiation use, biomass accumulation and partitioning. Field Crops Research, v.48, p.11-25, 1996.

RUDORFF, B.F.T.; BATISTA, G.T. Yield estimation of sugarcane based on agrometeorological-spectral models. Remote Sensing Environment, v.33, p.183-192, 1990.

USINA SÃO JOÃO. Banco de dados cadastrais da Usina São João. Araras, março de 2002.

TERUEL, D.A. Modelagem do índice de área foliar da cana-de-açúcar em diferentes regimes hídricos. Piracicaba: USP/ESALQ, 1995. 93p. (Dissertação - Mestrado).

XAVIER, A.C. Estimativa da dinâmica do índice de área foliar em uma microbacia hidrográfica por meio de técnicas de sensoriamento remoto. Piracicaba: USP/ESALQ, 2002. 111p. (Tese - Doutorado).

YATES, R.A. Assessment of the effect of inter-cane variability on the sampling and harvesting of sugarcane. Agronomy Journal, v.61, p.113$115,1969$.

ZULLO JR., J.; ARRUDA, F.B. Programa computacional para ajuste de equações em dados experimentais. Campinas: Instituto Agronômico de Campinas, 1986. 23p. (Boletim Técnico, 113).

Received July 17, 2003

Accepted December 17, 2004 